\title{
Kreatywność antropologiczna
}

\begin{abstract}
Abstrakt
Przedmiotem artykułu jest ogólna relacja między różnymi modelami ludzkiej natury a możliwymi różnymi sensami kreatywności. Gówna teza stwierdza, że ze względu na różne możliwe znaczenia nowości oraz związanej z nią kreatywności nie istnieje taki model, który by wykluczał możliwość zachowań kreatywnych. Jednakże najbardziej skrajny sens kreatywności zawierają tylko te modele, które negują materialną naturę człowieka określonej materialnie. W celu uzasadnienia takiego ujęcia odwołuję się szczególnie do koncepcji J. Ortegi oraz J.-P. Sartre’a.
\end{abstract}

Słowa kluczowe: ludzka natura, kreatywność, wolność.

\section{Anthropological creativity}

\begin{abstract}
The paper deals with the general relation between different models of human nature and possible diverse senses of creativity. The main thesis says that because of various potential meanings of newness and creativity connected with it there is no such model that principally excludes the possibility of creative behavior. However, the most extreme sense of creativity is contained only in these anthropological models that negate the material nature of man. To justify this opinion, I refer especially to the concepts formulated by J. Ortega y Gasset and J.-P. Sartre.
\end{abstract}

Keywords: human nature, creativity, freedom.

Na zjawisko kreatywności można patrzeć z różnych perspektyw - psychologicznej, pedagogicznej, socjologicznej, ekonomicznej, filozoficznej i zapewne wielu innych. Można postawić na pierwszym miejscu jedną z tych perspektyw, ale można też budować perspektywę multi- i interdyscyplinarną. Można analizować rozliczne

* Uniwersytet Marii Curie-Skłodowskiej, Instytut Filozofii. 
związane z kreatywnością zagadnienia szczegółowe, ale można też skupić się na jej najogólniejszych aspektach. Również sam termin „kreatywność” należy do określeń wieloznacznych. I nie chodzi nawet o jego różne teoretyczne wykładnie i interpretacje, czasami niejasności, związane z wielką ostatnio popularnością tego określenia, która często może prowadzić do jego treściowego rozmycia. Chodzi o inną zależność; o to mianowicie, że możemy ów termin stosować w odniesieniu do różnych poziomów ludzkiej aktywności: do ściśle rozumianego działania, ale też do postaw, pragnień, zamierzeń. Możemy go również stosować do konkretnych, szczegółowych form ludzkiego zachowania, jak i do zasadniczej postawy, jaką człowiek przyjmuje wobec życia. W tym ostatnim przypadku, gdy na pytanie o możliwość takiej kreatywności odpowie się pozytywnie, człowiek przekształca się w homo creator.

W niniejszym tekście analizowany jest tylko jeden z ogólnych aspektów kreatywności, a mianowicie pytanie o to, jakie relacje zachodzą między możliwością kreatywności a określonym rozumieniem człowieka, tj. zawartym w wybranych modelach antropologicznych. Innymi słowy, chodzi o pytanie, jak określona koncepcja człowieka wpływa na sposób rozumienia kreatywności. Ale również takie bardzo ogólne pytanie można formułować w różnorodnych kontekstach. Gdy na przykład wyjdziemy od podziału psychologicznych koncepcji człowieka na koncepcje behawiorystyczne, psychodynamiczne, poznawcze i humanistyczne (Kozielecki 2000), to będą one formułowały różne, czasami różne bardzo pryncypialnie ujęcia aktywności kreatywnej. Po jednej stronie znajdzie się wtedy koncepcja behawiorystyczna, która ogranicza zasadniczo możliwość spontanicznej kreatywności, po drugiej - koncepcja poznawcza, w której istnieje przestrzeń dla tego typu aktywności (tamże: 185-197). To tylko przykładowy podział. To, że ujęcia psychologiczne można dzielić również w inny sposób jest tu drugoplanowe. Podział ten pokazuje już jednak, że również w obrębie tego pytania wymagane są dodatkowe wyjaśnienia.

Perspektywa, w której tytułowe pytanie jest rozważane w tym artykule, to perspektywa filozoficzna. W jej ramach, by ją uszczegółowić, chodzi mi o określenie istotowych związków zachodzących między tym, kim jest człowiek, oraz tym, czym jest kreatywność. Problem można zatem ująć jako zasadnicze pytanie o sens kreatywności antropologicznej. Czy to, kim człowiek jest, określa jego kreatywność; czy też raczej to owa kreatywność określa to, kim człowiek jest? Dokładniej mówiąc, chodzi w poniższych rozważaniach o cztery pytania:

1) jakie są najogólniejsze modele antropologiczne?

2) jak poszczególne modele wpływają na możliwe w ich ramach rozumienie dziedziny kreatywności?

3) które z przypisywanych człowiekowi cech istotowych są najważniejsze w stosunku do możliwości kreatywności?

4) czy w ogóle którykolwiek z tych modeli wyklucza zasadniczo możliwość kreatywności? 
Dobór tych pytań nie jest przypadkowy. Zgodnie z czteroelementową strukturą sytuacji kreatywnej (Kopciuch 2015: 147-174) człowiek jest jej ważkim elementem, gdyż jest rozumiany jako podmiot kreatywności. Ponieważ ta struktura obejmuje także wysuwane przez podmiot cele, kontekst społeczno-kulturowy, w którym kreatywność ma swą dziedzinę, oraz samo działanie, to jest zrozumiałe, że samo tylko pytanie o człowieka w jego stosunku do kreatywności jest pytaniem cząstkowym. Ale bez odpowiedzi na nie nie możemy oczekiwać, że wyjaśnienie kreatywności będzie wyczerpujące. Prezentowany tu sposób rozumienia tych zagadnień ma jedynie dać wstępną orientację w ich zakresie. Ich pełniejsze przedstawienie wymagałoby dużo szerszych analiz ${ }^{1}$. Nawet jednak takie wstępne podziały i wyjaśnienia mają wartość poznawczą, zwłaszcza że pokazują zachodzące tu związki istotowe.

\section{Jakie są najogólniejsze modele antropologiczne?}

Podziały tych modeli były i są formułowane w różny sposób. Modele te są zwykle całościami złożonymi, zawierają odpowiedzi na wiele różnych pytań. Przykładem takiej złożonej klasyfikacji może być więc typologia Maxa Schelera, który wyróżnia pięć wielkich idei człowieka: 1) antropologię religijną; 2) antropologię racjonalistyczną; 3) antropologię naturalistyczną „pozytywną”; 4) antropologię natura listyczną „negatywną”; 5) ateistyczną koncepcję dumy i odpowiedzialności (Scheler 1987: 150-190).

W tym miejscu formułuję tylko taki podział, którego kryterium jest pozytywna lub negatywna odpowiedź na pytanie o istnienie ludzkiej natury. Kluczowe pytanie brzmi zatem: czy istnieje zestaw cech, których obecność określa bycie człowiekiem? By uniknąć nieporozumienia, trzeba od razu doprecyzować, że chodzi o cechy niebiologiczne, tj. cechy nienależące do przyrodniczego uposażenia człowieka.

Filozoficzne odpowiedzi na to pytanie można podzielić na trzy grupy. Pierwsza grupa obejmuje koncepcje, w których twierdzi się, że taka natura istnieje już jako „gotowa”, a zadanie człowieka sprowadza się jedynie do tego, by ją rozpoznać i urzeczywistnić. Grupa trzecia obejmuje koncepcje, w których się uznaje, że nie ma takiej natury, a zadanie człowieka polega na tym, by ją dopiero wytworzyć - poprzez własne wybory i działania. Z kolei grupa druga skupia w sobie takie koncepcje, które albo na miejsce niezmiennej i statycznej natury wstawiają naturę historyczną, kształtującą się w ludzkiej historii, albo też posługują się określeniem „ludzka natura”, jednakże natura ma w zasadzie charakter tylko potencjalny, swoją aktualność uzyskując dopiero w dziejach. To właśnie w nich człowiek może się dowiedzieć, kim jest, uzyskując samoświadomość. Układ tych najogólniejszych

\footnotetext{
1 Artykuł prezentuje fragmenty przygotowywanej obecnie książki, opatrzonej roboczym tytułem Zarys aksjologii kreatywności.
} 
odpowiedzi można zatem uszeregować następująco: odpowiedzi pozytywne - ludzka natura istnieje jako „gotowa”; odpowiedzi pośrednie - ludzka natura jest gotowa, ale istnieje tylko potencjalnie, dopiero w ludzkich dziejach staje się czymś rzeczywistym; odpowiedzi pośrednie - ludzka natura nie istnieje jako gotowa, dopiero w ludzkiej historii kształtuje się i zmienia; odpowiedzi negatywne - ludzka natura nie istnieje.

Takie modelowe odpowiedzi trzeba doprecyzować jeszcze jednym wyjaśniającym zastrzeżeniem. Rzecz bowiem w tym, że najprawdopodobniej nie jest w ogóle możliwe dosłowne odczytanie tezy negatywnej, stwierdzającej, że ludzka natura w ogóle nie istnieje. Rację ma Frederic Copleston, gdy - przedstawiając poglądy Sartre'a - pisze, że przecież muszą istnieć jakieś specyficznie ludzkie cechy, odróżniające gatunek ludzki od gatunku lwów (Copleston 2006: 307). Sytuacja staje się jednak jaśniejsza, gdy wprowadzimy odróżnienie natury formalnej i natury materialnej. Pierwsza oznacza tylko najogólniejsze ludzkie cechy, takie na przykład, jak wolność lub świadome odnoszenie się do własnej przeszłości i przyszłości (w nakierowanym wstecz wspomnieniu oraz w biegnącej do przodu wyobraźni). Są one na tyle ogólne, że poszczególne jednostki mogą je wypełniać konkretnymi, określonymi w szczegółach treściami. Z kolei natura materialna obejmuje już konkretne, określone w swych szczegółach własności. Ją właśnie mają na myśli zwolennicy stanowisk negatywnych.

\section{Jak poszczególne modele wpływają na możliwe $w$ ich ramach rozumienie kreatywności?}

Mogłoby się wydawać, że aktywność kreatywna będzie możliwa tylko w przypadku takich antropologii, które kwestionują istnienie gotowej ludzkiej natury. Wtedy bowiem brak takiej natury tworzy przestrzeń dla kreatywności, która ma za zadanie konstruować tę naturę. Zależność między ludzką naturą a kreatywnością nie jest jednak tak prosta. Również w przypadku gdy uznaje się istnienie gotowej ludzkiej natury, takie uznanie nie musi od razu oznaczać odrzucenia samej możliwości oraz sensu kreatywności. Tę bowiem można różnie lokalizować, zarówno co do jej usytuowania w strukturze ludzkiego zachowania (działań), jak i co do jej przedmiotu.

W celu wyjaśnienia tych zależności odwołam się raz jeszcze do pięciu typów nowości, które wyróżniłem, analizując kwestię wartości urzeczywistniających się w procesach globalizacyjnych (Kopciuch 2016a: 132-133). Są to następujące rodzaje nowości: 1) nowość ilościowa, która polega na powtarzaniu w innej przestrzeni pewnych rozwiązań; 2) nowość ilościowa, które polega na powtarzaniu danych rozwiązań w innym czasie; 3) nowość jakościowa polegająca na pojawianiu się w danej przestrzeni nieistniejących dotąd nigdzie rozwiązań; 4) nowość jakościowa, która polega na pojawianiu się nowych rozwiązań różnych od tego, co 
istniało dotychczas; 5) nowość mieszana, która łączy w sobie w różnych konfiguracjach wcześniejsze typy nowości. Jest to, rzecz jasna, podział nowości, a nie samej kreatywności, jednakże równie jasne jest, że nowość stanowi konstytutywny element kreatywności. Można więc z tego podziału wyprowadzać ważne konsekwencje, dotyczące samej kreatywności, a przede wszystkim dopuszczać możliwość kreatywności również w takich modelach, które uznają istnienie sprecyzowanej treściowo (materialnie) ludzkiej natury.

Pozytywna odpowiedź na pytanie o istnienie materialnie określonej ludzkiej natury oznacza ograniczenie możliwych form kreatywności. Z jej dziedziny zostaje przede wszystkim wykluczona ta jej postać, która dotyczy pryncypialnego wyznaczania tego, kim jest człowiek. Rozwiązanie jest już bowiem zawarte w tych określeniach, które są w definicji człowieka. Zadaniem poszczególnych indywiduów jest tylko urzeczywistnić w swoich działaniach te określenia. Ludzka natura determinuje bowiem zakres i ogólną treść ludzkiej aktywności. Co prawda człowiek może nie urzeczywistniać wszystkich tych cech, może też - zwłaszcza gdy idzie o określenia normatywne - wykraczać przeciwko nim, buntować się, stawiać opór. Takie zachowania traktowane są tu jednak jako jakiś rodzaj aberracji, wynaturzenie, a czasem także jako grzech. Gdyby przystać na taką formę kreatywności, musiałaby ona nabierać w tym modelu charakteru tylko negatywnego.

Czy to jednak znaczy, że model ten wyklucza w ogóle kreatywność pozytywną? Bynajmniej, odpowiedź twierdząca byłaby przedwczesna. Właśnie dlatego ważne są różne możliwe typy nowości. Jeżeli w konkretnym działaniu, w konkretach sytuacjach, pośród konkretnych uwarunkowań podejmuję aktywność wyznaczoną przez cechy, które swój fundament mają w ludzkiej naturze, to sens tego jest taki, że aplikuję ogólne rozwiązania do specyficznych, danych mi kontekstów - właśnie dlatego można tu zastosować kategorię nowości rozumianej ilościowo i to w różnych jej znaczeniach: zarówno jako nowość w czasie, jak i jako nowość w przestrzeni lub nowość mieszaną. Możliwe, że takie rozwiązanie nie wzbudzi akceptacji. Ktoś może powiedzieć następująco: czy to jest jeszcze w ogóle kreatywność, skoro de facto mamy tu do czynienia z repetycją czegoś, co istniało już wcześniej. Wątpliwość jest w pewnej mierze uzasadniona. Można jednak nieco ją zmniejszyć, odwołując się do odróżnienia twórczości obiektywnej i subiektywnej (Popek 2003: 16-24); ta druga również może zawierać powtórzenie rozwiązań sformułowanych już wcześniej, choć z tym ważnym zastrzeżeniem, że ten, kto jest kreatywny „subiektywnie”, o nich nie wie. Ale możliwy jest jeszcze inny wariant. Mam na myśli sytuację, gdy „jakoś” znam dane rozwiązanie, na przykład skomplikowane twierdzenie matematyczne, ale go nie rozumiem. Trud jego zrozumienia to w tym przypadku jego subiektywnie ważne odkrycie. Idąc tym tropem, możemy uzasadniać możliwość kreatywistycznej interpretacji powtórzenia tego, co już było, choć widać, że zarazem uwidaczniają się tu również momenty jakościowe. Takim nowym jakościowo elementem jest właśnie ów mój trud i wysiłek zrozumienia. 
To jednak nie wszystko. Te nowe, specyficznie indywidualne uwarunkowania sytuacyjne, w których działamy, są czymś, czego ani nigdy wcześniej, ani nigdzie indziej nie było. W tym sensie można powiedzieć, że te nowe zastosowania ogólnej natury są nowe w znaczeniu jakościowym.

Nie można też nie podkreślić, że cały czas mowa jest o kreatywności antropologicznej rozumianej jako typowa dla człowieka autokreacja. Stąd w tym sensie i zakresie każdy człowiek - właśnie jako człowiek - jest kreatywny, mimo że mogą to być różne formy kreatywności; różne, gdy chodzi o ich obiektywny wpływ i znaczenie, większe lub mniejsze powiązanie z wartościami.

By wesprzeć zasadność takiego szerokiego ujęcia kreatywności antropologicznej, odwołam się do przykładów: chrześcijańska wizja człowieka, mimo że operuje terminem „ludzka natura”, interpretuje na ogół ludzką odpowiedzialność na sposób indywidualny. W etyce Immanuela Kanta, mimo że maksymy, jakimi mamy się kierować, mają być różne, lecz zgodne z prawodawstwem powszechnym, widoczne jest wyraźnie preferowanie tego, co w człowieku ogólne. Kantowski imperatyw kategoryczny nakazuje działać tak, by sposób naszego działania mógł być racjonalnie (bez popadnięcia w sprzeczność) uznany za uniwersalny (Kant 1972: 53). W niezwykle precyzyjny sposób tę własność i kłopot Kantowskiej antropologii opisuje Nicolai Hartmann: „Kant nie ma na myśli podmiotu indywidualnego, lecz tylko etyczno-transcendentalny «podmiot w ogóle». Ten zaś zostaje utożsamiony z praktycznym rozumem, którego autonomiczną zasadą jest prawo moralne. A przynajmniej Kant nie odróżnia moralnej osoby jako «istoty rozumnej» od ogólnego praktycznego rozumu w takim sensie, jakiego by tego wymagał problem wolności, tzn. nie w sensie problemu, kto właściwie jest wolny i ponosi odpowiedzialność. Dlatego dla Kanta wraz z wykazaniem autonomii zasady była też wykazana wolność woli, a rozwiązanie antynomii kauzalnej wyczerpywało całość aporii" (Hartmann 1962: 692). Według Hartmanna Kantowska interpretacja człowieka jako osoby uniemożliwia uchwycenie tego, czym ta osoba rzeczywiście jest, tj. jej indywidualności i niepowtarzalności.

Te same wyjaśnienia, gdy idzie o możliwość kreatywności, należy odnieść do pierwszego modelu pośredniego, a więc do antropologii, która uznaje, że istnieje już określona ludzka natura, ale ujmuje ją jako coś, co urzeczywistnia się dopiero w czasie - według określonego, koniecznego schematu. Również tutaj konkretne działania realizują jedynie ogólną naturę, która początkowo istnieje tylko potencjalnie. Również tutaj powraca jednak charakterystyczne dla obu typów antropologii preferowanie tego, co ogólne. Niezwykle dobitnie uwidacznia się to w Heglowskiej interpretacji ludzkich dziejów, a zwłaszcza w zawartej w niej koncepcji wielkich historycznych jednostek. Taką wielką postacią zostaje człowiek, którego aktywność może stać się skutecznym instrumentem realizacji powszechnej treści dziejów (Hegel 2003: 48-52). To, co indywidulane, zostaje w ten sposób przedstawione jako narzędzie tego, co ogólne. 
Inne, już szersze rozumienie kreatywności pojawia się w drugim modelu pośrednim, w którym ludzka natura urzeczywistnia się w czasie, w dziejach, ale nie ma żadnego planu, który by determinował ten proces. Brak takiego określonego materialnie planu sprawia, że pojawia się szerokie pole dla ludzkiej kreatywności. Reprezentujący ten sposób myślenia hiszpański filozof José Ortega y Gasset pisze:

Człowiekowi przytrafiają się najróżniejsze formy bytowania. Ku zrozpaczeniu intelektualistów bycie - u człowieka - to czyste dzianie się, dzianie się z nim czegoś: jemu to przytrafia się być stoikiem, chrześcijaninem, racjonalistą czy witalistą. Jemu „przytrafia się być” kobietą paleolityczną i markizą Pompadour, Dżingis-chanem i Stefanem George, Peryklesem i Charlie Chaplinem. Człowiek nie jest przypisany na stałe żadnej z tych form: przechodzi przez nie - przeżywa je - jak strzała Zenona, która na przekór Zenonowi przelatuje przez chwilę bezruchu (Ortega 1992: 196).

Przytoczony fragment uwidacznia prawie wszystkie najważniejsze momenty charakterystyczne dla tego modelu antropologii: 1) człowiek jest bytem dynamicznym i przyjmuje $\mathrm{w}$ historii nader różne formy bycia; 2) żadna $\mathrm{z}$ tych form bycia nie jest stała; 3) żadna z nich nie jest uniwersalna; 4) wszystkie są metafizycznie przypadkowe („przytrafiają się”).

Szeroki zakres ludzkiej autokreacjonistycznej aktywności prezentuje się również w relacji między człowiekiem a techniką. Ortega traktuje ją wręcz jako synonimiczną z istotą człowieka: „Nie ma człowieka bez techniki” (tamże: 259). Człowiek nie traktuje techniki jako zwykłego narzędzia, służącego sprawnej realizacji potrzeb; jest ona raczej tym, co te potrzeby znosi, likwiduje, wytwarzając w ten sposób właściwy obszar ludzkiego życia. Dla Ortegi człowiek nie znajduje zaspokojenia $\mathrm{w}$ tym, co obiektywnie potrzebne, lecz w tym, co obiektywnie zbyteczne $-\mathrm{tj}$. w tym, co wymyślone, sztuczne, dodane poprzez ludzką kreatywność do świata przyrodniczego. Rzeczywisty świat ludzkiego życia jest ludzkim wytworem. W tym właśnie świecie prezentuje się ludzka aktywistyczna sprawczość, wolność i kreatywność:

Życie każdego z nas jest czymś, co nie zostało nam dane gotowe, sprezentowane, lecz tym, co należy wykonać;

(...) człowiek w samym rdzeniu swojej istoty znajduje się przede wszystkim w sytuacji technika. Życie jest dla niego głównie i nade wszystko wysiłkiem, aby zaistniało to, czego jeszcze nie ma, a mianowicie on, on sam; korzysta on w tym celu z tego, co jest; jednym słowem jest produkcją (tamże: 272-273).

Wypowiedzi Ortegi brzmią często tak skrajnie², że mogłaby powstać myśl, że jego stanowisko jest powtórzeniem poglądów rozwijanych przez Sartre’a. Takie

\footnotetext{
2 Pisze on na przykład: „Człowiek jest bytem tworzącym samego siebie (...). Człowiek jednak nie tylko musi stwarzać siebie, musi - i to jest najważniejsze - określić, czym sam będzie”. „Podsumowując,
} 
przypuszczenie byłoby nieuzasadnione. Ortega nie traktuje bowiem możliwości ludzkiej kreatywności jako niczym nieograniczonej. I co ważne, powiedziałbym, że jest to zarówno limitacja deskryptywna, jak i normatywna. Przez pierwszą rozumiem to, że u Ortegi człowiek działa zawsze w kontekście tej sytuacji, w jakiej się w świecie pojawił; ona zaś wyznacza zakres danych człowiekowi możliwości: człowiek jest wolny wśród okoliczności, a nie od okoliczności. Przez limitację drugą rozumiem natomiast to, że, jak Ortega podkreśla, człowiek w swoich aktualnych wyborach powinien nawiązywać do wyborów z przeszłości, inaczej jego życie stanie się kiepskim dramatem, tj. sztuką, której części lub wątki są pozbawione jakiegokolwiek związku. Nie jest w tym miejscu ważne, czy takie limitacje dadzą się pogodzić z innymi twierdzeniami Ortegi - to kwestia interesująca dla historyków filozofii. Tu ważne jest tylko to, że te limitacje powodują, że Ortegowskie rozumienie zakresu i siły ludzkiej kreatywności nie jest skrajne.

Skrajne rozumienie tej antropologicznej kreatywności pojawia się dopiero w modelu ostatnim, traktującym kreatywność jako niczym nieograniczoną. Człowiek jest tu rozumiany jako istota pozbawiona jakiejkolwiek materialnej określoności; człowiek sam siebie w pełni kształtuje i nigdy nie jest w tej kreatywności przez cokolwiek ograniczany. Takie właśnie rozumienie ludzkiej wolności i kreatywności można zilustrować stanowiskiem, które prezentuje Jean-Paul Sartre. Wymowne pod tym względem są już same wyjaśnienia, jakie Sartre podaje, gdy tłumaczy, czym jest egzystencjalizm: jest to sposób myślenia, który głosi, że w przypadku człowieka egzystencja poprzedza esencję. Pisze on:

Egzystencjalizm ateistyczny reprezentowany przeze mnie jest bardziej konsekwentny. Głosi on, że jeżeli nie istnieje Bóg, to istnieje przynajmniej jeden byt, którego egzystencja poprzedza istotę, jeden byt, który istnieje przed możliwością zdefiniowania go przez czyjś umysł, i że tym bytem jest człowiek (...). Co znaczy w tym przypadku, że egzystencja poprzedza istotę? To znaczy, że człowiek najpierw istnieje, zdarza się, powstaje w świecie, a dopiero później się definiuje. Człowieka w pojęciu egzystencjalistycznym nie można zdefiniować dlatego, że jest on pierwotnie niczym. Będzie on czymś dopiero później, i to będzie takim, jakim się sam uczyni (Sartre 2001: 131).

Najpierw zatem człowiek jest, a dopiero potem staje się jakimś - w wyniku podejmowanych decyzji i działań. Przy czym proces ten, póki człowiek żyje, nigdy nie jest zamknięty - człowiek zawsze jest tym, czym nie jest: jest projektem, tym, kim chce być. Ów cechujący człowieka dynamizm - twierdzi Sartre - jest bezgraniczny i absolutnie wolny, nic nie jest w stanie go ograniczyć. To niezwykle ważna różnica

człowiek nie ma natury, ma tylko...historię. Inaczej mówiąc, czym przyroda jest dla rzeczy, tym dla człowieka - jako res gestae (...) - są dzieje. Po raz kolejny stajemy wobec możliwości zastosowania do rzeczywistości ludzkiej pojęć teologicznych. Święty Augustyn mówi: Deus cui hoc est natura quod fecerit... [łac. - Bóg, którego naturą jest to, co zrobił... (...). Podobnie człowiek nie ma innej «natury» poza tym, co zrobił" (Ortega 1992: 190). 
w zestawieniu z poglądami Ortegi. Dla Sartre’a nic ludzkiej wolności w tworzeniu siebie nie ogranicza - ani sytuacje, ani przeszłość, ani opinie czy rady, jakich nam udzielają inni: „(...) człowiek skazany jest na wolność”; „W ogóle nie ma żadnych wskazówek na świecie" (Sartre 2002: 139, 149). Tego typu czynniki nie mają bowiem znaczenia obiektywnego, lecz tylko subiektywne: są czymś dopiero w kontekście projektu, który człowiek sam dla siebie tworzy. Jeżeli przeszłość kogoś ogranicza, to dlatego, że sformułował on dla siebie projekt, w którym teraźniejszość jest kontynuacją przeszłości. 0 ile brak pieniędzy kogoś ogranicza, to dlatego, że wymaga ich ów projekt, który ktoś sam dla siebie wymyślił. Dla Sartre'a nic samo przez się nie jest przeszkodą. Bycie przeszkodą lub środkiem sprzyjającym pozostaje $\mathrm{z}$ natury odniesione do projektu.

Nie można w bardziej skrajny sposób pomyśleć możliwości, jakie stoją przed ludzką kreatywnością. Podlega jej wszystko. Każde znaczenie w świecie, każdy sens jest wytworem ludzkiego sprawstwa. Sartre oczywiście nie twierdzi, że szczegółowe, konkretne działania podejmowane w konkretnej sytuacji nie są niczym wyznaczone, ale tym, co je wyznacza, nie jest jakiś czynnik heteronomiczny - tym czynnikiem jest sam człowiek i jego pierwotny wybór. W takim pierwotnym wyborze własnej egzystencji człowiek określa kształt swoich wyborów szczegółowych.

\section{Które z przypisywanych człowiekowi cech istotowych są zasadnicze w stosunku do możliwości działań i postaw kreatywnych?}

Powyższy systematyczny podział oraz ilustrujące go teorie są już dostateczną podstawą, by udzielić odpowiedzi na to pytanie. Zasadniczą ludzką cechą fundującą możliwość analizowanej tu kreatywności jest wolność metafizyczna (wzgl. ontologiczna). Rozumiem ją jako podstawowy rodzaj wolności, różnych od tych jej odmian, które mają charakter dziedzinowy, gdyż pozostają związane z konkretnym obszarem naszej aktywności. W tym „dziedzinowym” sensie możemy na przykład mówić o wolności politycznej, religijnej, gospodarczej czy obyczajowej.

Do tej metafizycznej wolności dołączają się inne ludzkie zdolności: zdolność uprzedmiotowienia siebie i postawienia siebie jako zadania do rozwiązania; zdolność bycia innym niż inni; zdolność uprzedmiotowiania własnych pragnień i pytania o ich zasadność, zdolność kierowania się wolą, a nie tylko skłonnościami psychobiologicznymi3; zdolność aktywności (a nie tylko receptywności); wrażliwość na wartości i związana z nią wrażliwość na normatywność; zdolność wyobrażania sobie i planowania; zdolność realizowania tego, co wyobrażone i zaplanowane. Powyższa lista zdolności nie jest pełna, ale daje już obraz tego, jak wiele zdolno-

\footnotetext{
3 Niezwykle cenne rozróżnienia przeprowadza w tym zakresie Harry Gordon Frankfurt, który traktuje wolę jako efektywne pragnienie drugiego rzędu (Frankfurt 1997: 21-39).
} 
ści tworzy podstawę dla kreatywności. Istotne jest również, że te zdolności można traktować jako elementy ludzkiej natury formalnej.

Ważnym obszarem do szczegółowego przebadania, jaki się stąd wyłania, jest obszar problemów wyznaczonych przez pytanie o stosunek między wolnością a innymi typami kreatywności. Wydaje się bowiem, że ta zależność dla różnych typów kreatywności może być inna. Natchniona twórczość genialnego artysty może być niewolna, nie tracąc swej bardzo wysokiej wartości.

I wreszcie ostatnie pytanie: czy w ogóle którykolwiek z tych modeli wyklucza zasadniczo możliwość kreatywności? Odpowiedź jest negatywna. Sama kreatywność mieści w sobie różne możliwe sensy, co sprawia, że nawet w modelu pozytywnym, uznającym istnienie określonej materialnie ludzkiej natury, możliwe są postawy i zachowania kreatywne. Po pierwsze, polegają one na twórczym aplikowaniu do konkretnej sytuacji tych form zachowania, które są wyznaczone przez ludzką naturę. Skoro te sytuacje są każdorazowo inne, jedyne w swoim rodzaju, niepowtarzalne, to ogólnie rzecz biorąc, takie samo działanie nie będzie nigdy takim samym działaniem w ścisłym tego słowa znaczeniu. Po drugie, weźmy dla przykładu biblijne określenie człowieka jako „pana przyrody”, zawarte w sformułowaniu: czyńcie sobie ziemię poddaną. Rzecz jasna, można je potraktować jako element materialnie wyznaczonej ludzkiej natury, ale równie jasne jest, że takie określenie można pogodzić z geniuszem ludzkiej wyobraźni, inteligencji i kreatywności, jakie leżą u podstaw tego opanowywania przyrody. Nauka, a zwłaszcza powiązana z nią technika jest tego znakomitym wyrazem. Po trzecie, nawet jeśli przyjmiemy taką materialną określoność, to nie wyklucza to, że związane z człowiekiem własności - takie jak myślenie, racjonalność, wyobraźnia, uzdolnienia, talenty - mogą być dane w różnym stopniu, przez co różne jednostki mogą być mniej lub bardziej kreatywne. Po czwarte, nawet w tym skrajnie pozytywnym modelu uznaje się, że cechy ludzkiej natury dla swego pełnego urzeczywistnienia wymagają ludzkiej aktywności i wysiłku.

Naszkicowane rozwiązania są oparte na stanowisku pluralistycznym. Jak można dowodzić wielości wartości, różnych „równoprawnych” kryteriów ich hierarchizowania (bez popadnięcia w relatywizm ${ }^{4}$ ), różnych ich danych historycznie „równorzędnych" systemów ${ }^{5}$, tak można też wykorzystać opcję pluralistyczną do wyjaśnienia różnych zasadniczych zagadnień związanych z kreatywnością.

Inna sprawa, że powyższe refleksje mają tylko charakter wstępny, a ponadto dotykają tylko jednego aspektu tego ogólnego problemu. Jeżeli ten ogólny problem

\footnotetext{
${ }^{4}$ Pisałem o tym w artykule Multikulturalizm, wartości oraz relatywizm i (lub) pluralizm (Kopciuch 2016b).

5 Przykładem takiej możliwości są teorie wielości cywilizacji (np. stanowisko Oswalda Spenglera lub Arnolda Toynbee'go).
} 
sformułujemy jako pytanie o relację między tym, kim człowiek jest a jego kreatywnością, to oprócz kwestii relacji między ludzką naturą a kreatywnością pojawia się również inne, równie podstawowe pytanie: jakie możliwości stoją przed ludzką kreatywnością w trzech innych modelach, tj. w modelu teoretycznym, praktycznym oraz teoretyczno-praktycznym. Podział ten zastosowałem niegdyś w analizach problematyki z obszaru filozofii dziejów (Kopciuch 2014: 43-92; Kopciuch 2015: 64-68), ale jest to podział na tyle ogólny, że da się go użyć również w odniesieniu do zagadnień antropologicznych, tym bardziej że jego rdzeń stanowią różne odpowiedzi na pytanie o sprawczą i twórczą rolę człowieka w świecie. Model teoretyczny charakteryzuje się bowiem uznaniem, że rola człowieka w świecie jest tylko narzędziowa; człowiek jest tylko instrumentem obiektywnych prawidłowości i tendencji, wyznaczających bieg procesów kulturowych poniekąd niezależnie od świadomie wysuwanych przez człowieka celów. Model praktyczny - przeciwnie - uznaje, że jest pewien istotny wymiar świata kulturowego, który nie zaistnieje bez nakierowanej nań świadomej, intencjonalnej aktywności ludzkiej. Można tu powiedzieć, że ludzkie tworzenie jest źródłem tego nowego, istotnego wymiaru kultury. Wreszcie model teoretyczno-praktyczny uznaje, że ludzka sprawcza aktywność staje się skuteczna tylko wtedy, gdy pozostaje zgodna z obiektywnymi prawidłowościami świata. Analiza tych trzech wariantów oraz pojawiających się w ich obrębie szczegółowych modyfikacji wymaga jednak przeprowadzenia odrębnych badań. Gdy idzie o najogólniejsze konteksty kreatywności, jej najogólniejsze kategorie i powiązania, wiele jest jeszcze ciągle niewiadomych.

\section{Bibliografia}

Copleston F. (2006) Historia filozofii, t. 9: Od Maine de Birana do Sartre'a, przeł. B. Chwedeńczuk, Warszawa, Instytut Wydawniczy Pax.

Frankfurt H. G. (1997) Wolność woli i pojęcie osoby, tłum. J. Nowotniak w: Filozofia moralności. Postanowienie i odpowiedzialność moralna, wyb. i wstęp J. Hołówka, Warszawa, Wydawnictwo Spacja - Fundacja Aletheia, s. 21-39.

Hartmann N. (1962) Ethik, wyd. 4 niezmienione, Berlin, Walter de Gruyter \& Co.

Hegel G. W. F. (2003) Wykłady o filozofii dziejów, tłum. A. Zieleńczyk, Warszawa, De Agostini - Altaya.

Kant I. (1972) Krytyka praktycznego rozumu, tłum. J. Gawecki, Warszawa, PWN.

Kopciuch L. (2014) Szkice systematyczne z filozofii dziejów, Lublin, Wydawnictwo UMCS.

Kopciuch L. (2015) Kryzysy, kreatywność i wartości, Lublin, Wydawnictwo UMCS. 
Kopciuch L. (2016a) Powinność i wartość globalizacji (z przykładami stanowisk dziewiętnastowiecznych i późniejszych), „Kultura - Historia - Globalizacja”, nr 18, s. 121137, http://www.khg.uni.wroc.pl [dostęp: 20.04.2018].

Kopciuch L. (2016b) Multikulturalizm, wartości oraz relatywizm i (lub) pluralizm, „Idea. Studia nad strukturą i rozwojem pojęć filozoficznych”, nr XXVIII/1, s. 5-21.

Kozielecki J. (2000) Psychologiczne koncepcje człowieka, wyd. X, Warszawa, Wydawnictwo Akademickie „Żak”.

Ortega y Gasset J. (1982) Rozmyślania o technice, tłum. H. Woźniakowski w: J. Ortega y Gasset, Bunt mas i inne pisma socjologiczne, wyb. S. Cichowicz, Warszawa, PWN, s. 235-326.

Ortega y Gasset J. (1992) Dzieje jako system, tłum. A. Jancewicz w: J. Ortega y Gasset, Po co wracamy do filozofii, wyb. i wstęp S. Cichowicz, Warszawa, Wydawnictwo SPACJA, s. 171-207.

Popek S. (2003) Człowiek jako jednostka twórcza, Lublin, Wydawnictwo UMCS.

Sartre J.-P. (2001) Egzystencjalizm jest humanizmem, tłum. J. Krajewski w: J.-P. Sartre, Problem bytu i nicości. Egzystencjalizm jest humanizmem, Warszawa, De Agostini - Altaya, s. 118-189.

Scheler M. (1987) Człowiek i historia, tłum. A. Węgrzecki w: M. Scheler, Pisma z antropologii filozoficznej i teorii wiedzy, tłum., wstęp i przypisy S. Czerniak, A. Węgrzecki, Warszawa, PWN, s. 150-190. 